\title{
FORMULASI DAN UJI STABILITAS FISIK GRANUL INSTAN SERBUK KERING TANGKAI GENJER (Limnocharis flava (L.) Buchenau.) SEBAGAI SUPLEMEN PENAMBAH SERAT
}

\author{
${ }^{1}$ Patihul Husni, ${ }^{2}$ Muchamad Luthfi Fadhiilah, ${ }^{3}$ Uswatul Hasanah \\ ${ }^{1}$ Departemen Farmasetika dan Teknologi Farmasi, Fakultas Farmasi, Universitas Padjadjaran, Jl. Raya Bandung \\ Sumedang KM.21, Jatinangor 45363 \\ ${ }^{2}$ Program Studi Farmasi, Fakultas Matematika dan Ilmu Pengetahuan Alam, Universitas Al-Ghifari, Jl. \\ Cisaranten Kulon No.140, Bandung, 40292 \\ ${ }^{3}$ Fakultas Farmasi, Universitas Andalas, Kampus Limau Manis, Padang, 25163
}

\begin{abstract}
ABSTRAK
Serat dibutuhkan dalam pencernaan adalah agar proses pencernaan dapat bekerja secara maksimal. Genjer (Limnocharis flava (L.) Buchenau.) merupakan tanaman yang bagian tangkainya banyak mengandung serat. Kandungan serat yang tinggi pada genjer terutama pada bagian tangkainya berpotensi untuk dikembangkan sebagai suplemen makanan penambah serat berupa granul instan. Tujuan penelitian ini adalah untuk mendapatkan formula terbaik granul instan secara fisik. Granul instan dibuat dengan metode granulasi basah menggunakan variasi konsentrasi PVP sebagai pengikat. Uji stabilitas fisik granul instan dilakukan pada suhu kamar selama satu bulan meliputi uji waktu alir, sudut diam, indeks kompresibilitas, kandungan lembab dan waktu larut. Hasil penelitian menunjukkan bahwa waktu alir granul 8-14 detik untuk 100 gram granul, sudut diam sekitar $40^{\circ}$, indeks kompresibilitas 11-15\%, kandungan lembab sekitar 2\% dan waktu larut 1-2 menit. Berdasarkan hasil uji stabilitas fisik, formula terbaik granul instan serbuk kering tangkai genjer adalah F2 dengan komposisi serbuk kering tangkai genjer $100 \mathrm{mg}$, laktosa 70\%, PVP 3\%, aspartam 1,5\%, manitol 20\%, Natrium Benzoat $0,5 \%$, Green tea flavor $5 \% \mathrm{~b} / \mathrm{b}$ dan etanol qs dengan total bobot granul $1000 \mathrm{mg}$.
\end{abstract}

Kata kunci: Serat, genjer, granul instan, granulasi basah, PVP

\begin{abstract}
Fiber is needed in digestion so that the digestive process work optimally. Limnocharis flava (L) Buchenau is a plant whose stems contain a lot of fiber. The high fiber content has the potential to be developed as a food supplement in the form of instant granules. The study aimed to get the best formula of instant granules physically. The instant granules were prepared by wet granulation method using varian concentration of PVP as a binder. Physical stability tests of the instant granules were carried out at room temperature for one month storage including test of flow time, angle of repose, compressibility index, moisture content, and time of granules to dissolve. Study results showed that the flow time of granules was 8-14 seconds for 100 gram granules, angle of repose was around $40^{\circ}$, compressibility index was $11-15 \%$, moisture content was around $2 \%$ and time of granules to dissolve was 1-2 minutes. Based on the results of physical stability test, it can be concluded that the best formula for the instant granules was F2 which containing dry powder of Limnocharis flava stem $100 \mathrm{mg}$, lactose 70\%, PVP 3\%, aspartame $1.5 \%$, mannitol $20 \%$, sodium benzoate $0.5 \%$, green tea flavor $5 \% \mathrm{w} / \mathrm{w}$ and ethanol qs with a total granule weight of $1000 \mathrm{mg}$.
\end{abstract}

Keywords: Fiber, Limnocharis flava, instant granule, wet granulation, PVP

\section{PENDAHULUAN}

Serat sangat diperlukan dan sangat penting dalam pencernaan (Turner dan
Lupton, 2011). Fungsi serat dalam pencernaan adalah agar dapat bekerja secara maksimal dalam melakukan proses 
pencernaan makanan yang masuk. Saluran usus dalam tubuh manusia membutuhkan asupan serat dan vitamin. Tubuh manusia, khususnya organ saluran pencernaan idealnya membutuhkan asupan serat yang cukup. Dalam satu hari minimal harus ada sekitar 25 gram sampai dengan 38 gram serat pangan atau dietary fiber yang masuk ke dalam saluran usus halus dan usus besar manusia. Serat pangan atau serat diet dapat diperoleh dengan cara mengkonsumsi bahan pangan dari jenis sayuran, buah-buahan, sereal, kacang-kacangan atau biji-bijian (Slavin, 2005).

Salah satu jenis sayuran yang banyak mengandung serat adalah genjer (Limnocharis flava (L.) Buchenau.). Hasil analisis serat genjer adalah sebesar 1,31\% (Permatasari, 2012). Kandungan lainnya dalam genjer juga cukup baik untuk dikonsumsi. Hasil penelitian menunjukkan bahwa dalam $100 \mathrm{~g}$ bagian yang dapat dimakan dari genjer terkandung $90 \mathrm{~g}$ air, 35 kkal energi, 1,7 g protein, 0,2 g lemak, 7,7 g karbohidrat, 0,4 g abu, $62 \mathrm{mg}$ kalsium, 33 $\mathrm{mg}$ fosfor, 2,1 $\mathrm{mg}$ besi, total $3800 \mu \mathrm{g}$ karoten, 0,07 $\mathrm{mg}$ tiamin dan $54 \mathrm{mg}$ vitamin C (Mahmud dkk., 2009). Genjer biasanya dikonsumsi oleh masyarakat lokal sebagai sayuran (Juhaeti, 2013). Kandungan serat yang tinggi pada genjer terutama pada bagian tangkainya berpotensi untuk dikembangkan sebagai suplemen makanan penambah serat. Apalagi seiring dengan berkembangnya trend kembali ke alam saat ini, penggunaan obat tradisional dan suplemen makanan terutama yang berasal dari tumbuh-tumbuhan terus meningkat.

Suplemen menurut definisi dari BPOM adalah produk yang dimaksudkan untuk melengkapi kebutuhan zat gizi makanan, mengandung satu atau lebih bahan berupa vitamin, mineral, asam amino atau bahan lain (berasal dari tumbuhan atau bukan tumbuhan) yang mempunyai nilai gizi dan atau efek fisiologis dalam jumlah terkonsentrasi. Suplemen tidak boleh diklaim mampu mencegah atau menyembuhkan penyakit tertentu. Suplemen hanya bisa mengurangi risiko terjadinya sesuatu akibat penyakit tersebut, bukan mengobati penyakitnya (Santoso, 2011).

Bentuk sediaan suplemen makanan yang juga memberikan penyajian yang praktis dan menarik adalah granul instan. Granul instan dapat mengandung bahan herbal. Salah satunya adalah serbuk kering tangkai genjer. Oleh karena itu, serbuk kering tangkai genjer sangat berpotensi untuk dikembangkan dalam bentuk sediaan suplemen granul instan yang banyak mengandung serat untuk mencegah kekurangan serat dalam tubuh. Kebaruan (novelty) dari penelitian ini adalah pengembangan formula serbuk tangkai genjer yang tinggi serat menjadi sediaan granul instan yang praktis dan lebih enak dikonsumsi untuk memenuhi kebutuhan 
serat sehari-hari. Pentingnya inovasi penelitian ini adalah untuk membantu memenuhi kebutuhan serat pada masyarakat melalui sediaan minuman granul instan yang lebih menarik untuk dikonsumsi. Pengembangan formula dan serangkaian evaluasi fisik sediaan penting dilakukan untuk mendapatkan formula terbaik sehingga penelitian ini bertujuan untuk mendapatkan formula granul instan serbuk tangkai genjer yang stabil secara fisik selama waktu penyimpanan. Sediaan dalam bentuk granul lebih stabil secara fisika dan kimia serta memiliki peluang yang lebih rendah untuk terbentuknya cake dibandingkan serbuk. Keuntungan lain dari sediaan berbentuk granul adalah memiliki sifat alir yang baik dan mudah untuk disiapkan ketika akan dikonsumsi (Djarot dan Badar, 2017).

\section{METODE PENELITIAN}

\subsection{Alat}

Moisture balance (G-Won Hitech), neraca analitik (Shimadzu), oven (Memmert), penangas air (Memmert), $\mathrm{pH}$ meter (Hanna), alat uji sifat alir, ayakan mesh 30, mesh 12 dan mesh 16, jangka sorong (Tricle Brand), mortir dan stamper, dan stopwatch (Casio).

\subsection{Bahan}

\section{Genjer (Limnocharis flava}

Buchenau.), polivinil pirolidon (PVP), manitol, laktosa, aspartame, natrium benzoat, etanol 95\%, dan green tea flavor.

\subsection{Metode}

\subsubsection{Pengumpulan Bahan Tanaman}

Tanaman diperoleh dari daerah Rancaekek, Kabupaten Bandung.

\subsubsection{Determinasi Tanaman}

Determinasi tanaman dilakukan di Laboratorium Taksonomi Tumbuhan, Departemen Biologi, Fakultas Matematika dan Ilmu Pengetahuan Alam Universitas Padjajaran, Jatinangor, Sumedang.

\subsubsection{Pembuatan Serbuk Kering Tangkai \\ Genjer \\ Genjer segar dipotong dan diambil} bagian batangnya saja, lalu batangnya diiris tipis-tipis selanjutnya dikeringkan dalam oven pada suhu $45-50^{\circ} \mathrm{C}$ selama 50 menit setelah kering dihaluskan menggunakan blender lalu diayak.

\subsubsection{Formulasi Granul Instan Serbuk}

Kering Tangkai Genjer

Tabel 1. Formula Granul Instan

\begin{tabular}{lccc}
\hline & \multicolumn{3}{c}{ Jumlah } \\
\cline { 2 - 4 } Nama Bahan & F1 & F2 & F3 \\
\hline $\begin{array}{l}\text { Serbuk Kering } \\
\text { Tangkai } \\
\text { (mg) }\end{array}$ & & 100 & 10 \\
$\begin{array}{l}\text { Polivinil } \\
\text { Pirolidon (\% b/b) }\end{array}$ & 100 & & \\
$\begin{array}{l}\text { Manitol (\% b/b) } \\
\text { Aspartam (\% b/b) }\end{array}$ & 1,5 & 1,5 & 1,5 \\
$\begin{array}{l}\text { Natrium Benzoat } \\
\text { (\% b/b) }\end{array}$ & 0,5 & 0,5 & 0,5 \\
$\begin{array}{l}\text { Green Tea Flavor } \\
\text { (\% b/b) }\end{array}$ & 5 & 5 & 5 \\
\end{tabular}


Husni P, Fadhiilah ML, Hasanah U, JIF Farmasyifa, 3(1): 1-8

\begin{tabular}{llll} 
Etanol 95\% & qs & qs & qs \\
Laktosa (mg) & 72 & 70 & 68 \\
\hline
\end{tabular}

Bobot total adalah $1000 \mathrm{mg}$

\subsubsection{Pembuatan Granul Instan}

Pembuatan granul instan dilakukan dengan metode granulasi basah. Bahanbahan diayak dengan ayakan nomor 30 dan masing - masing bahan ditimbang sesuai formula yang akan dibuat. Manitol, aspartam, dan natrium benzoat sedikit demi sedikit dicampurkan dalam wadah kemudian ditambahkan laktosa dan diaduk sampai homogen. Green tea flavor dan PVP dimasukkan ke dalam campuran tersebut lalu diteteskan etanol 95\% secukupnya sampai terbentuk massa yang dapat dikepal. Massa yang dapat dikepal tersebut diayak menggunakan ayakan nomor 12. Granul yang dihasilkan dikeringkan pada suhu 40$50^{\circ} \mathrm{C}$ selama 24 jam. Granul kering diayak dengan ayakan nomor 16. Granul yang didapatkan dilakukan uji stabilitas fisik granul.

\subsubsection{Uji Stabilitas Fisik Granul Instan}

Uji stabilitas fisik granul instan dilakukan selama satu bulan dimana granul instan disimpan pada suhu kamar. Pengujian dilakukan setiap tujuh hari yaitu pada hari ke-0, 7, 14, 21 dan 28. Setiap pengujian dilakukan secara triplo. Evaluasi stabilitas ini meliputi lima parameter uji yaitu waktu alir, sudut diam, indeks kompresibilitas, kandungan lembab dan waktu larut.

\section{Waktu Alir}

Waktu alir adalah waktu yang dibutuhkan sejumlah granul untuk mengalir dalam suatu alat. Sifat alir ini dapat dipakai untuk menilai efektivitas bahan pelicin, dimana adanya bahan pelicin dapat memperbaiki sifat alir suatu granulat sebanyak 100 gram. Kecepatan alir granul dinyatakan dalam satuan gram/detik dan granul tersebut mengalir tidak lebih dari 10 detik (Voigt, 1994).

\section{Sudut Diam}

Sudut diam merupakan suatu sudut tetap yang terjadi antara timbunan partikel bentuk kerucut dengan bidang horizontal jika sejumlah serbuk dituang ke dalam alat pengukur. Sudut diam yang baik antara 25$40^{\circ}$ (Lachman, 1994). Sudut diam ditentukan dengan persamaan Tan $\alpha=\mathrm{h} / \mathrm{r}$ dimana $\alpha$ adalah sudut diam, h adalah tinggi kerucut dan r adalah jari-jari kerucut.

\section{Indeks Kompresibilitas}

Sejumlah 25 gram sampel (M) dimasukkan ke dalam gelas ukur $100 \mathrm{ml}$, lalu diukur volumenya (V bulk). Gelas ukur yang berisi sampel tersebut kemudian diketuk-ketukkan sebanyak 300 kali dan akan didapatkan volume mampat (V mampat). Nilai indeks kompresibilitas dihitung menggunakan persamaan (1), (2) dan (3) di bawah ini.

(1) Bj mampat $=\frac{M}{V \text { mampat }}$

(2) Bj bulk $=\frac{\mathrm{M}}{\mathrm{V} b u l k}$ 
Formulasi Dan Uji Stabilitas Fisik Granul...

(3) Indeks kompresibilitas(\%) =

$\frac{\text { Bj mampat-Bj bulk }}{\text { Bj Mampat }} \times 100 \%$

\section{Kandungan Lembab}

Pada uji ini digunakan moisture balance. Pada alat tersebut dimasukkan 1 gram granul dalam aluminium foil lalu ditara dan diukur kandungan lembabnya dengan menekan tombol start maka akan didapatkan persen kandungan lembab. Kandungan lembab yang baik adalah 1-5\% (Voigt, 1994).

\section{Waktu Larut}

Uji waktu larut dilakukan dengan menimbang sebanyak 20 gram granul. Granul yang telah ditimbang selanjutnya dilarutkan ke dalam 200 ml air. Kemudian dihitung kecepatan melarutnya dengan stopwatch. Syarat waktu yang diperlukan granul untuk melarut kurang dari 5 menit (Siregar, 1992). Air yang digunakan adalah air dingin dengan pengadukan secara kontinyu saat granul dilarutkan.

\section{HASIL DAN PEMBAHASAN}

Hasil determinasi menunjukkan bahwa tanaman yang digunakan pada penelitian ini adalah Limnocharis flava (L.) Buchenau. dengan nama lokal genjer. Tangkai genjer dikeringkan dan diserbukkan serta dijadikan komponen dalam formula granul instan.

Granul yang dihasilkan dari ketiga formula tidak memiliki perbedaan secara visual dari segi warna, aroma maupun rasa yang dihasilkan. Hal ini dikarenakan tidak

terdapat perbedaan konsentrasi pada bahan tambahan pemanis, pengaroma maupun pewarna dari ketiga formula granul instan. Perbedaan terdapat pada konsentrasi polivinil pirolidon yang digunakan yang berfungsi sebagai bahan pengikat dalam pembuatan granul.

Uji stabilitas fisik granul instan dilakukan pada suhu kamar selama satu bulan meliputi uji waktu alir, sudut diam, indeks kompresibilitas, kandungan lembab dan waktu larut. Pemeriksaan waktu alir ini dilakukan terhadap granul yang telah dikeringkan. Hal ini dilakukan dengan tujuan untuk mengetahui apakah granul instan tersebut memenuhi persyaratan sehingga diharapkan akan menghasilkan granul yang baik. Hasil uji waktu alir menunjukkan bahwa F1 dan F2 memenuhi syarat yang telah ditetapkan oleh Siregar (1992) yaitu memiliki waktu alir kurang dari 10 detik untuk 100 gram granul. Sedangkan untuk F3 tidak memenuhi syarat (Gambar 1). Hal ini dikarenakan pada F3 mengandung PVP dalam konsentrasi yang lebih banyak dibandingkan formula lainnya dimana sifat dari PVP adalah higroskopis (Rowe et al, 2009). 


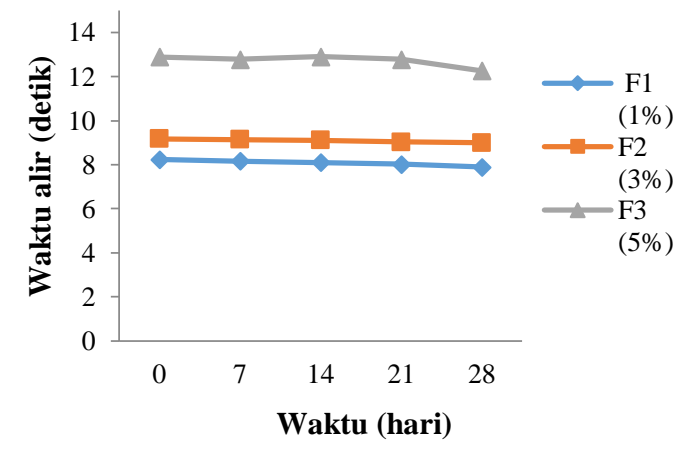

Gambar 1. Hasil uji waktu alir $(n=3)$

Sudut diam merupakan uji granul yang penting untuk mengetahui sifat alir dari granul. Serbuk akan membentuk kerucut, semakin datar kerucut yang dihasilkan maka sudut diamnya makin kecil (Voight, 1994). Nilai dari sudut diam yang dapat diterima antara $20-40^{\circ}$ nilai dari sudut diam sangat jarang di bawah $20^{\circ}$ dan rata rata sampai $40^{\circ}$ yang menunjukkan aliran yang baik serta di atas $50^{\circ}$ menunjukkan serbuk susah mengalir (Ansel, 1989). Semua formula granul menunjukkan aliran yang baik. Hubungan antara formula dengan konsentrasi PVP yang berbeda terhadap sudut diam granul instan dapat dilihat pada Gambar 2.

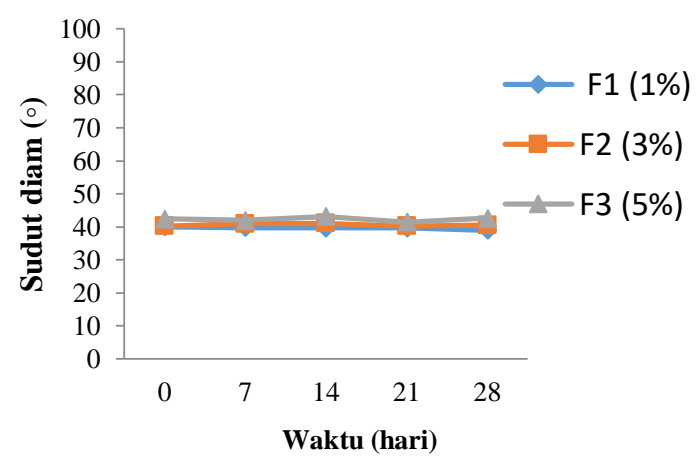

Gambar 2. Hasil uji sudut diam $(n=3)$
Uji indeks kompresibilitas merupakan suatu pengukuran kekuatan “jembatan" serbuk (powder bridge strength) dan stabilitas. Nilai indeks kompresibilitas yang rendah dari suatu bahan mengindikasikan sifat aliran yang lebih baik dibandingkan nilai indeks kompresibilitas yang tinggi. Nilai indeks kompresibilitas kurang dari $10 \%$ menunjukkan aliran yang sangat baik sedangkan nilai indeks kompresibilitas lebih dari $38 \%$ menunjukkan aliran yang sangat buruk (Shah et al, 2008). Granul instan serbuk kering tangkai genjer memiliki nilai indeks kompresibilitas sebesar $11-15 \%$ dan termasuk kategori bahan yang memiliki sifat alir yang baik. Bahan yang memiliki nilai indeks kompresibilitas di bawah $15 \%$ akan memiliki sifat untuk mengalir bebas (free flowing) (Bacher et al, 2008).

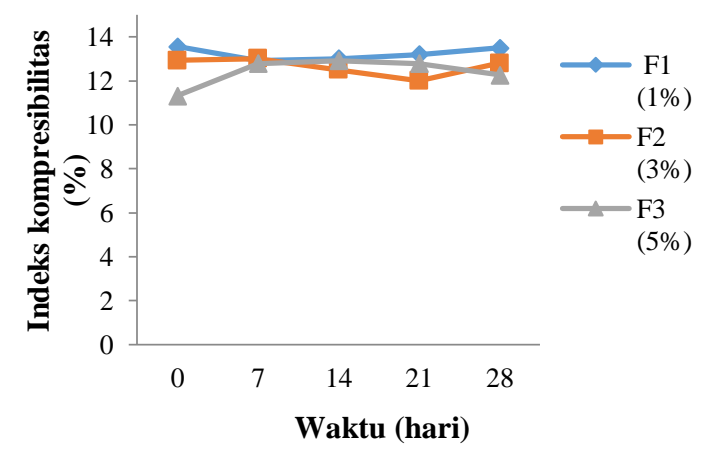

Gambar 3. Hasil uji indeks kompresibilitas $(\mathrm{n}=3)$

Uji kandungan lembab dimaksudkan untuk mengetahui banyaknya bagian zat yang mudah menguap termasuk air yang terdapat dalam granul instan akibat proses pemanasan yang terjadi pada granul pada 
waktu pengeringan. Gambar 4 menunjukkan bahwa ketiga formula memenuhi persyaratan sebagai granul yang baik dimana persentase kandungan lembabnya sesuai dengan persyaratan yaitu antara $2-4 \%$ (Lachman dkk, 1994).

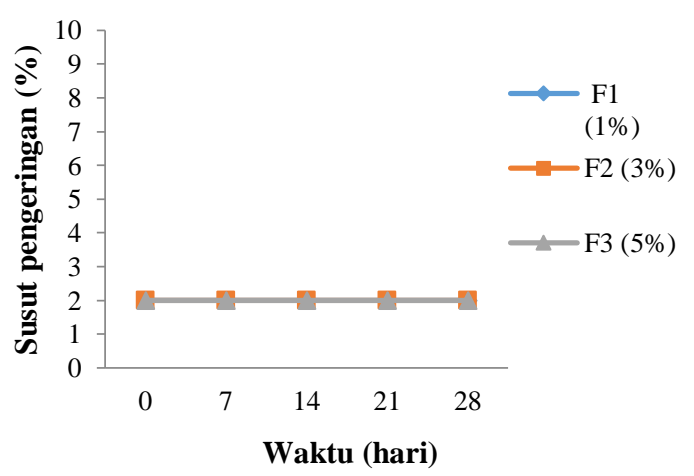

Gambar 4. Hasil uji susut pengeringan ( $\mathrm{n}=$ 3)

Syarat waktu melarut yang baik menurut Siregar (2010) adalah kurang dari 5 menit. Hasil uji yang diperoleh menunjukan bahwa ketiga formulasi granul instan memenuhi syarat waktu larut (Gambar 5). Waktu larut pada ketiga formula dipengaruhi oleh variasi konsentrasi PVP dalam granul namun pada Gambar 5 terlihat bahwa semua formula memenuhi syarat waktu larut yaitu granul larut tidak lebih dari 5 menit.

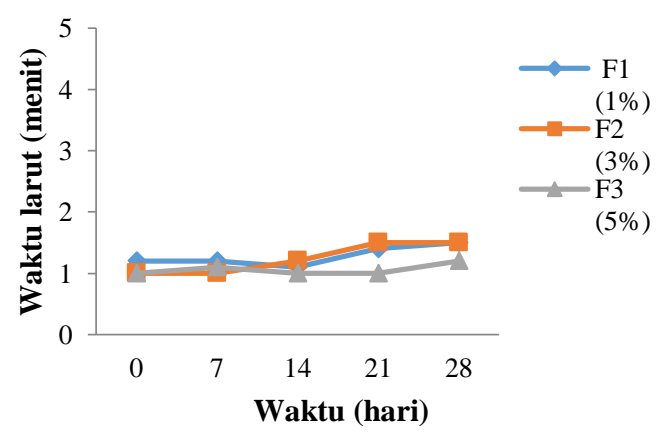

Gambar 5. Hasil uji waktu larut $(n=3)$

\section{KESIMPULAN}

Formulasi terbaik granul instan serbuk kering tangkai genjer berdasarkan evaluasi fisik selama satu bulan adalah F2 yang mengandung serbuk kering tangkai genjer $100 \mathrm{mg}$, laktosa 70\% b/b, PVP 3\% b/b, aspartam 1,5\% b/b, manitol $20 \% \mathrm{~b} / \mathrm{b}$, natrium benzoat $0,5 \% \mathrm{~b} / \mathrm{b}$, dan green tea flavor $5 \% \mathrm{~b} / \mathrm{b}$, dengan total bobot granul $1000 \mathrm{mg}$.

\section{UCAPAN TERIMA KASIH}

Terima kasih kepada Program Studi Farmasi, Fakultas Matematika dan Ilmu Pengetahuan Alam, Universitas Al-Ghifari atas dukungan fasilitas dalam penelitian ini.

\section{DAFTAR PUSTAKA}

Ansel HC., 1989. Pengantar Bentuk Sediaan Farmasi, Edisi Keempat. Penerjemah Farida Ibrahim. Penerbit UI Press. Jakarta.

Bacher C, Olsen PM, Bertelsen P, dan Sonnergaard JM., 2008. Compressibility and Compactibility of Granules Produced by Wet and Dry Granulation. International Journal of Pharmaceutics. 358:69-74.

Djarot P dan Badar M., 2017. Formulation and Production of Granule From Annona Muricata Fruit Juice as Antihypertensive Instant Drink. International Journal of Pharmacy and Pharmaceutical Sciences. 9(5):1822.

Juhaeti T., 2013. Respon Genjer \{Limnocharis flava (L.) Buchenau.\} Terhadap Pemupukan Dan Potensi Gizinya untuk Diversivikasi Konsumsi Sayuran. Berita Biologi. 12(1):107116.

Lachman L, Lieberman HA, dan Kanig JL., 1994. Teori dan Praktek Farmasi Industri Jilid I Edisi II. Penerjemah 
Siti Suyatmi. Penerbit Universitas Indonesia. Jakarta.

Mahmud MK, Hermana, Zulfianto NA, Ngadiarti I, Apriyantono RR, Hartati B, Bernadus, dan Tinexcelly., 2009. Tabel Komposisi Pangan Indonesia. 64. PT. Elex Media Komputindo. Jakarta.

Permatasari M., 2012. Perubahan Aktivitas Antioksidan Tanaman Genjer (Limnocharis flava) Akibat Pengukusan. Skripsi. Fakultas Perikanan dan Ilmu Kelautan Institut Pertanian Bogor. Bogor.

Rowe RC, Sheskey PJ, dan Quinn ME., 2009. Handbookof Pharmaceutical Excipients Sixth Edition. Pharmaceutical Press and The American Pharmacists Association. USA.

Santoso A., 2011. Serat Pangan (Dietary Fiber) dan Manfaatnya Bagi Kesehatan. Magistra. 75:35-40.

Shah RB, Tawakkul MA, dan Khan MA., 2008. Comparative Evaluation of Flow for Pharmaceutical Powders and Granules. AAPS PharmSciTech. 9(1):250-258.

Siregar, C., 1992. Proses Validasi Manufaktur Sediaan Tablet. ITB. Bandung.

Slavin JL., 2005. Dietary Fiber and Body Weight. Nutrition. 21:411-418.

Turner ND, dan Lupton JR., 2011. Dietary Fiber. Advances in Nutrition. 2(2):151152.

Voight R., 1994. Buku Pelajaran Teknologi Farmasi, Edisi Kelima. Penerjemah Drs. Soendani Noerono. Gadjah Mada University Perss. Yogyakarta. 